\title{
Iban Sebuyau Youth Slang: Radial Network Category Framework Analysis Slanga Remaja Iban Sebuyau: Analisis Kerangka Kategori Jaringan
Radial
}

Clinton Ringit*, Hamidah Abdul Wahab

Fakulti Bahasa dan Komunikasi, Universiti Malaysia Sarawak (UNIMAS), 94300 Kota Samarahan, Sarawak, Malaysia

*Corresponding author: 18020153@siswa.unimas.my

Article history: Received: 09 March 2019 Received in revised form: 20 August 2019 Accepted: 22 August 2019 Published online: 31 December 2019

\begin{abstract}
Slang is a free-grammatical rule of language phenomenon that exhibits the invention of vocabulary in a community groups in order to strengthen social identity. Overall, there are 15 data of Iban Sebuyau teenagers slang which has been acquired and separated into noun categories (eight data) and verbs (seven data). This study will analyze seven types of words of Iban Sebuyau teenagers' slang in Sarawak via the verb category. Besides, the slang of Iban Sebuyau teenagers' data will be examined based on the Radial Network Category Framework as suggested by Lakoff (1987). Accordingly, this study applied qualitative methods to obtain field sampling based on 10 teenagers in Sebuyau which has been selected based on their comprehension on the slang. As a result, the findings shows that there are in total of 7 data of Iban Sebuyau teenagers slang has been obtained in verb categories such as merueh, ngaga' peta, ngangat nyawa, belagu, nunjuk langit, melabur, and fogging. Overall, the Radial Network Category Framework approach able to describe the extensive meaning of Iban Sebuyau teenagers slang.
\end{abstract}

Keywords: Slang; meaning extension; Iban youth; Radial Network Category Framework

Abstrak

Slanga merupakan fenomena berbahasa yang bebas daripada peraturan tatabahasa yang memperlihatkan penciptaan kosa kata dalam kelompok masyarakat bagi mengukuhkan identiti sosial. Keseluruhannya, terdapat 15 data slanga remaja Iban Sebuyau yang diperoleh dan terbahagi kepada kategori kata nama (lapan data) dan kata kerja (tujuh data). Kajian ini akan menganalisis tujuh perkataan slanga remaja Iban Sebuyau, Sarawak melalui kategori kata kerja. Selain itu, data slanga remaja Iban Sebuyau, Sarawak akan dianalisis berdasarkan Kerangka Kategori Jaringan Radial yang disarankan oleh George Lakoff (1987). Sehubungan dengan itu, kajian ini menerapkan kaedah kualitatif untuk mendapatkan data di kawasan lapangan berdasarkan 10 informan remaja Iban yang telah dipilih di sekitar daerah Sebuyau berpandukan kefahaman mereka mengenai slanga sebelum pengkaji menjalankan kajian ini. Hasilnya, kajian ini memperoleh tujuh data bahasa slanga remaja Iban Sebuyau kategori kata kerja seperti, merueh, ngaga' peta, ngangat nyawa, belagu, nunjuk langit, melabur, dan fogging. Secara keseluruhannya, pendekatan Kerangka Kategori Jaringan Radial dapat menghuraikan peluasan makna slanga remaja Iban Sebuyau.

Kata kunci: Slanga; peluasan makna; remaja Iban; Kerangka Kategori Jaringan Radial

(C) 2020 Penerbit UTM Press. All rights reserved

\subsection{PENGENALAN}

Bahasa menjadi wadah yang penting dalam menyampaikan sesuatu maklumat dan simbol yang arbitrari untuk sesuatu kumpulan sosial yang berkerjasama (Bloch dan Trager, 1942). Penggunaan bahasa ini kita anggap sebagai sesuatu yang lazim sehinggakan kita jarang membuat penelitian mengenainya. Menurut Chaedar (1993), bahasa menjadi saluran yang penting untuk berkomunikasi dalam satu kitaran bersosialisasi sama ada dilakukan melalui kaedah yang formal atau tidak formal, manakala Bloch dan Trager (1942) turut menyatakan bahawa bahasa adalah sesuatu wahana yang digunakan secara bebas dalam suatu kelompok tertentu. Trend penggunaan bahasa slanga khususnya dalam kalangan golongan remaja dilihat semakin berleluasa. Pendapat ini disokong oleh Ayub (2016) menyatakan bahawa penggunaan bahasa slanga sentiasa menjadi pilihan dalam pertuturan dalam kelompok sosial untuk mengetengahkan idea, sekali gus penggunaan bahasa slanga turut digunakan dalam penulisan akhbar, skrip drama atau lagu. Kini, penggunaan bahasa slanga dalam kalangan remaja dilihat menjadi kekangan dalam mengekalkan bahasa yang indah dan standard. Menurut Teo (1996) slanga ialah pola bahasa yang bersifat kompleks dan telah di gunakan sejak tamadun manusia wujud terdahulu. Eble (1996) pula mentakrifkan bahasa slanga sebagai bentuk perkataan dan ungkapan seharian yang berperanan dalam mengekalkan gaya sosial pertuturan sesuatu kumpulan. Bahasa slanga selalu berubah dari semasa ke semasa mengikut perkembangan zaman. Bahasa slanga ini lazimnya dikategorikan dalam percakapan 
yang tidak rasmi. Sehubungan dengan itu, penjelasan makna slanga berdasarkan tokoh-tokoh sarjana menerangkan bahasa slanga digunakan oleh kelompok tertentu untuk menyampaikan makna dan hanya difahami oleh kelompok sosialnya. Walau bagaimanapun, bahasa ini tidak bertahan dengan lama ekoran perubahan zaman. Pendapat ini disokong oleh Eble (1996) yang menyatakan bahawa bahasa slanga tidak menunjukkan ciri-ciri yang akan kekal lama kerana berpandukan kepada trend semasa melalui peristiwa yang tertentu dan difahami oleh komuniti semasa yang mengujarkannya. Dalam pada itu, bahasa slanga antara bahasa yang sangat menarik untuk dikaji, misalnya dari aspek makna teras dan makna pinggiran dalam ujaran tersebut sebagaimana kajian ini yang akan dijalankan.

\subsection{OBJEKTIF KAJIAN}

Terdapat dua objektif dalam penyelidikan ini, iaitu:

i. mengenal pasti tujuh perkataan slanga remaja Iban Sebuyau kategori kata kerja,

ii. menganalisis bahasa slanga remaja dari sudut peluasan makna berdasarkan Kerangka Kategori Jaringan Radial yang disarankan oleh Lakoff (1987).

\subsection{SOROTAN KAJIAN}

Penulisan ini bukan sahaja merujuk kepada fenomena berbahasa, tetapi penulisan ini merupakan satu medium yang digunakan untuk menjadi rekod bahasa yang boleh dilihat berdasarkan pendokumentasian teks sebagai rujukan untuk generasi yang akan datang tentang sesuatu bahasa. Dalam konteks kajian ini, penelitian bahasa slanga adalah melibatkan hubungan bahasa dengan sosiobudaya khususnya kumpulan sosial yang menggunakannya. Kajian mengenai bahasa slanga merupakan kajian yang sangat menarik untuk dikaji bagi melihat fenomena penggunaan bahasa sama ada kajian di dalam atau luar negara. Sarjana-sarjana lepas yang menjalankan kajian mengenai bahasa slanga bagi konteks dalam negara seperti Sulaiman, Chien, Boon, dan Yusuf (2012), Subet dan Daud (2017), Hashim, Mahmoor, Ahmad dan Yahya (2016), Yusob dan Zakaria (2016), dan Sintian (2015). Manakala, sarjana luar negara yang melakukan kajian mengenai fenomena bahasa slanga pula ialah Zhou dan Fan (2013), Pradianti (2013), Mutonya (2007), Izmaylova, Zamaletdinova dan Zholshayeva (2017), dan Nguemo (2016). Rasional pemilihan kajian-kajian lepas daripada dalam dan luar negara dalam penyelidikan ini adalah sebagai panduan kepada pengkaji untuk melihat objektif kajian, metodologi dan dapatan kajian agar kelompangan dalam setiap penyelidikan tersebut dapat memacu dan dimanfaatkan oleh kajian pengkaji semasa.

Penyelidikan bahasa slanga yang dijalankan oleh Sulaiman et al.(2012) bertujuan untuk mengenal pasti kesahan makna eksplisit dan implisit bahasa slanga remaja Melayu dan Cina dengan menerapkan Teori Relevan. Dari sudut metodologi kajian, Sulaiman et al. (2012) menyasarkan golongan remaja yang berbangsa Cina dan Melayu, iaitu masing-masing 10 orang responden yang berumur antara 17 ke 26 tahun. Kaedah judgemental method diterapkan dalam penyelidikan ini, iaitu responden dipilih berdasarkan ciri-ciri latar belakang pelajar Institut Pengajian Tinggi (IPT), mat rempit, lelaki lembut, atau remaja yang pernah disabitkan dengan kesalahan penggunaan dadah. Setiap responden yang dipilih akan ditemu bual secara berperingkat. Kajian ini mendapati bahawa penggunaan bahasa slanga dalam perbualan harian remaja yang berbangsa Melayu dan Cina ini telah mewujudkan penciptaan kosa kata atau istilah yang baharu dan memiliki makna yang difahami oleh kelompok sosial mereka sahaja. Keputusan yang diperoleh dalam kajian ini mendapati makna tersurat dan tersirat bahasa slanga adalah relevan dan sesuai untuk dikaji dengan peredaran zaman seperti kencing (menipu), lauk (perempuan yang diajak untuk aktiviti seks), anak burung (perempuan untuk seks), wa lau yeh (kata seru), zhu a $i$ (sangat angkuh), dan kuda putih (polis trafik). Sehubungan itu, penggunaan bahasa figuratif ini dapat dihuraikan dari sudut makna implisit dan eskplisit dengan menggunakan Teori Relevan.

Seterusnya, kajian dalam bidang semantik dan makna konotasi slanga pelacur oleh Subet dan Daud (2017) berfokus untuk menganalisis makna slanga dalam mandala bahasa pelacuran. Penyelidikan ini menggunakan kaedah temu bual, iaitu kaedah judgemental method yang melibatkan dua orang pelacur sekitar Bukit Bintang, Kuala Lumpur. Setiap perbualan dirakamkan menggunakan teknik rakaman tidak langsung. Terdapat 16 data dalam slanga pelacuran yang diperoleh dalam kajian ini. Kajian pengkaji ini mendapati tuturan kosa kata slanga hanya difahami oleh kelompok mereka sahaja dalam bidang pelacuran. Dalam temu bual yang dijalankan oleh pengkaji Subet dan Daud (2017) mendapati penggunaan kod slanga dalam bidang pelacuran merupakan satu wadah untuk berahsia daripada diketahui umum. Misalnya, kosa kata slanga pelacuran, iaitu bertahan (kekuatan lelaki), kerja (melacur) dan sales (keuntungan). Selain itu, kerahsiaan menggunakan slanga ini menjamin privasi si pelacur semasa bekerja. Setiap tuturan slanga yang dinyatakan dalam perkhidmatan ini pada mereka adalah bersifat kiasan dan halus kerana perkataan tersebut hanya difahami oleh kelompok sosial mereka sahaja. Dalam pada itu, kajian ini memperlihatkan fenomena bahasa yang digunakan dalam kumpulan tertentu sebagai strategi menyembunyikan makna sebenar daripada orang awam.

Sementara itu, kajian Hashim, Mahmoor, Ahmad dan Yahya (2016) pula membincangkan tentang penggunaan slanga dalam penulisan komik. Kajian oleh Hashim, Mahmoor, Ahmad dan Yahya (2016) dijalankan untuk mengenal pasti penggunaan kata slanga dalam Siri Komik Ana Muslim dan menganalisis bentuk dan makna kata slanga yang digunakan dalam Siri Komik Ana Muslim. Kajian ini menerapkan Kaedah Analisis Kandungan melalui siri komik Majalah Ana Muslim, iaitu siri komik Pada Suatu Hari yang diterbitkan oleh Blue-T Publication Sdn. Bhd. pada Mei 1998. Kaedah Analisis Kandungan digunakan untuk menjelaskan kandungan dalam suatu komunikasi bagi mengesahkan hipotesis kepelbagaian mesej. Makna slanga yang diperoleh turut dianalisis dengan menggunakan kaedah pragmatik. Hasilnya, kajian ini memperoleh 29 data slanga berdasarkan tiga kategori, iaitu kategori Kata Ganti Nama Diri Orang (lima data), Ekspresi (lapan data) dan Bahasa Asing (enam belas data). Sebagai contoh, data slanga pastu dalam siri komik tersebut sebenarnya diterbitkan daripada penanda wacana "Selepas itu" yang hanya disingkatkan dengan mewujudkan perkataan pas untuk kata "selepas" dan $t u$ untuk kata "itu" yang akhirnya digabungkan. Kajian ini memberi tanggapan kepada pembaca bahawa penggunaan kata slanga bukan sahaja wujud secara verbal, tetapi digunakan secara berleluasa dalam bidang penulisan.

Penyelidikan oleh Yusob dan Zakaria (2016) pula memaparkan penelitian bahasa slanga yang terdapat dalam perfileman di Malaysia. Kajian ini meneliti tentang penggunaan bahasa slanga yang digunakan dalam filem-filem aksi tempatan dan mengenal pasti golongan kata bahasa slanga yang paling banyak digunakan dalam filem-filem aksi tempatan. Penyelidikan ini dijalankan berdasarkan pendekatan 
deskriptif kualitatif yang dikenal pasti serta dianalisis secara induktif dan deskriptif untuk mencapai objektif kajian. Yusob dan Zakaria (2016) berpandukan kepada tiga buah perfileman Malaysia, iaitu Gengsterock Kasi Sengat (2015), Ophilia (2015) dan Lu Mafia, Gua Gangster (2016). Data bahasa slanga yang telah dikumpul akan direkodkan secara bertulis. Selepas itu, data-data slanga tersebut dicerakinkan mengikut golongan kata. Kajian ini memperoleh 47 data melalui ketiga-tiga buah filem tersebut. Kajian ini juga memperlihatkan ketiga-tiga buah filem tersebut mempunyai persamaan kata slanga yang diujarkan seperti awek, gua, lu, blah dan tere. Kekerapan penggunaan kata slanga juga memaparkan kategori kata kerja antara leksikal yang paling banyak digunakan dalam ujaran slanga yang diikuti oleh kategori kata nama dan kata sifat. Manakala, penggunaan kata ganti diri kurang dituturkan dan hanya digunakan untuk menggantikan kata nama. Keseluruhannya, industri perfileman menggunakan kata slanga untuk menunjukkan variasi pertuturan dalam realiti suatu kehidupan.

Kajian Sintian (2015) pula bertujuan untuk mengenal pasti leksikal slanga yang dituturkan oleh pelajar Kadazan Dusun dan mengenal pasti fungsi leksikal yang diujarkan dan menjelaskan faktor timbulnya leksikal slanga tersebut. Dalam pada itu, seramai 20 orang pelajar etnik Kadazan Dusun di Universiti Pendidikan Sultan Idris dipilih menjadi responden kajian. Data-data slanga yang diperoleh menggunakan teknik temu bual bersemuka jenis semi struktur. Pendekatan Model Sosiologi Bahasa Deskriptif yang disarankan oleh Fishman (1991) dijadikan entiti utama untuk menyelesaikan permasalahan, objektif dan soalan kajian. Hasilnya, kajian ini mendapati bahawa pelajar mempunyai kecenderungan menuturkan bahasa slanga ini dalam kalangan kumpulan mereka sahaja yang bertujuan untuk bergurau, slogan dan menyatakan perasaan. Selain itu, faktor pengungkapan leksikal slanga ialah sifat terbawa-bawa daripada kebiasaan dalam persekitaran keluarga dan masyarakatnya di negeri Sabah. Contohnya, tatap BN, ini kali lah dan lain kali lah antara slogan yang digunakan dalam slanga pelajar Kadazan Dusun. Ringkasnya, leksikal slanga yang dituturkan dalam kalangan pelajar Kadazan Dusun mempunyai ciri-ciri yang diadaptasi melalui sifat kedaerahan dan etnik, serta pengalaman hidup pelajar.

Selain itu, kajian-kajian mengenai slanga di luar negara juga aktif dilakukan bagi memahami inti fenomena berbahasa ini. Sementara itu, kajian Zhou dan Fan (2013) mengupas mengenai slanga bahasa Amerika dari perspektif bidang Sosiolinguistik. Kajian ini dijalankan untuk meneliti ciri-ciri bahasa slanga, faktor penggunaan bahasa slanga individu dan faktor sosial penggunaan slanga yang memberi impak serta fungsi sosial bahasa Amerika. Kajian oleh Zhou dan Fan (2013) merujuk contoh asal daripada buku teks semasa, sebahagian filem Amerika yang asal, kamus slanga Amerika kontemporari serta novel untuk mendapatkan data melalui 3 bahagian yang telah dinyatakan, iaitu ciri-ciri bahasa slanga, faktor penggunaan bahasa slanga individu dan faktor sosial penggunaan slanga. Hasilnya, ciri-ciri bahasa slanga di Amerika merangkumi faktor kejenakaan, keringkasan, keaslian, dan ketidakstabilan. Manakala, faktor penggunaan bahasa slanga individu dipengaruhi oleh jantina, pekerjaan dan umur. Penggunaan slanga dari perspektif faktor sosial pula melibatkan dadah, homoseksualiti dan kekerasan. Fungsi sosial slanga Amerika memaparkan pengejaran identiti diri sendiri, emosi dan pencapaian kesopanan telah mempengaruhi penggunaan slanga. Walau bagaimanapun, kajian yang melibatkan penggunaan slanga khususnya dalam kajian dilihat sangat rumit disebabkan bahasa slanga berkembang berdasarkan peredaran zaman yang menempuh pelbagai cabaran.

Penyelidikan oleh Pradianti (2013) pula bertujuan untuk meneliti kosa kata slanga yang dituturkan oleh pelajar-pelajar sekolah tinggi dari aspek proses morfologi kosa kata slanga dan faktor penggunaannya dalam perbualan harian mereka. Kajian ini menggunakan kaedah soal selidik dan temu bual melalui beberapa orang informan yang dipilih. Frekuensi dalam kajian ini mendapati leksikal slanga yang dicipta sendiri memaparkan peratusan penggunaan yang paling kerap, iaitu 30.56\%. Hasil yang seterusnya mendapati kosa kata slanga melalui perspektif pengadunan mencapai $20.14 \%$ dan leksikal pinjaman sebanyak $13.19 \%$ perkataan. Selain itu, kajian Pradianti (2013) mendapati faktor penggunaan slanga disebabkan pelajar-pelajar ingin mengatakan sesuatu kata dengan cara yang lebih senang jika dibandingkan dengan menggunakan perkataan yang lebih standard seperti perkataan hendak berdating yang digantikan dengan slanga ngedate. Penggunaan slanga juga digunakan untuk menunjukkan sifat kemarahan mereka. Setiap kata slanga yang dituturkan hanya difahami oleh mereka sahaja di samping sebagai wadah untuk bergurau. Jelas menunjukkan bahawa kajian-kajian tentang slanga memberi implikasi pemaknaan dan juga kosa kata.

Mutonya (2007) dalam kajian beliau cuba untuk menganalisis bahasa Swahili yang disusun semula oleh komuniti jalan Nairobi, iaitu Kinoki. Kajian ini dijalankan untuk mengadaptasi alat penyelidikan Sosiolinguistik dan memberi tumpuan kepada perbezaan Kinoki dari slanga bandar yang dominan seperti Sheng. Kajian ini turut membincangkan sikap terhadap istilah yang berbeza yang merujuk kepada komuniti jalanan, aktiviti jalanan dan pegawai penguatkuasa undang-undang. Kaedah kajian ini melibatkan pemerhatian peserta, wacana spontan, dan tinjauan interaktif selama beberapa bulan. Dua sampel penduduk Nairobi berusia 10-14 tahun mengambil bahagian dalam kajian ini. Kumpulan pertama terdiri daripada 20 kanak-kanak yang beralih antara pusat tanpa tempat tinggal dan pusat pemulihan, dan mahir dalam Kinoki. Kumpulan kedua pula terdiri daripada 20 pelajar sekolah yang menuturkan bahasa Sheng sebagai bahasa pertama mereka. Dapatan kajian ini memaparkan keputusan bahawa kanak-kanak jalanan menunjukkan perbezaan dengan rakan sekolah mereka yang tinggal di kawasan kejiranan berpendapatan rendah di bandar ini. Hal ini menunjukan pentakrifan semula pejoratif yang mendedahkan dan penghinaan orang jalanan serta gaya hidup mereka. Sebaliknya, Kinoki memberi kuasa kepada masyarakat yang terpinggir untuk membina identiti positif, untuk memperbaiki perwakilan gaya hidup jalanan, dan untuk mentakrifkan semula neologism yang merujuk kepada kumpulan-kumpulan tertentu serta pengalaman luar mereka. Contohnya, slanga seperti wakora (penjahat), wanyang'anyi (rampasan) dan Malaya (pelacuran) yang menjadi identiti rahsia kelompok pengguna bahasa Kinoki. Kesimpulannya, kajian ini memantapkan penggunaan bahasa slanga Kinoki dalam persekitaran bahasa kompleks Nairobi dan merungkai peranan sosialnya.

Kajian oleh Izmaylova, Zamaletdinova dan Zholshayeva (2017) pula berkaitan dengan kajian ciri-ciri slanga remaja yang menggunakan bahasa Inggeris moden. Penyeldikan ini dijalankan adalah untuk menganalisis penggunaan ujaran slanga dalam kalangan generasi muda. Secara dasarnya, definisi slanga mula menarik perhatian filologi moden. Kini, wujud sebilangan besar pengertian slanga yang sering bertentangan antara satu sama lain. Penulis mendakwa bahawa slanga Rusia mempunyai sebilangan besar peminjaman bahasa Inggeris. Kajian ini mempunyai pengkhususan untuk menganalisis konsep pemuda bahasa Inggeris moden. Seramai 30 pelajar dari kursus kedua telah mengambil bahagian dalam soal selidik. Pelajar menganggap bahawa slanga remaja merupakan sebahagian daripada komunikasi antara rakan sebaya. Perkataan sebegini membolehkan mereka mengekalkan hubungan dengannya sahabat, berkomunikasi, belajar tahap baru penggunaan slanga remaja dalam ucapan. $80 \%$ daripada responden telah menjawab soalan Adakah anda menggunakan kata-kata seorang pemuda slang komunikasi dengan rakan-rakan?. Sebahagian besar telah menjawab bahawa mereka menggunakan perkataan slanga di mana-mana (58\%). 71\% daripada yang ditemu ramah pelajar hanya menggunakan pinjaman dalam ucapan. Ramai yang muda orang $(80 \%)$ telah menyatakan bahawa mereka memahami nilai anglicisme yang digunakan oleh mereka. Lebih separuh daripada pelajar (40\%) menggunakan pinjaman atas tabiat. Kebanyakan pelajar (63\%) pasti, memberi kesan negatif pada ucapan, tetapi 
$37 \%$ daripada responden yakin bahawa penggunaan slanga bahasa Inggeris menggalakkan pengayaan perbendaharaan kata. Penyelidikan ini menggalakkan penyelesaian masalah penentuan, entiti dan ciri tersendiri utama fenomena yang dikaji.

Nguemo (2016) dalam penelitian beliau mengenai penggunaan slanga yang dimanipulasikan dalam komunikasi pelajar Nigeria. Kajian ini dijalankan untuk meneliti pengguna bahasa memanipulasi bahasa slanga untuk memenuhi keperluan komunikasi mereka yang membawa kepada evolusi beberapa jenis yang selain memenuhi keperluan ini. Seterusnya kajian ini dilakukan untuk meneliti slanga bahasa Inggeris sebagai salah satu jenis dari penggunaan awalnya terhad kepada kelazimannya di kalangan pelajar Nigeria dari Universiti Ahmadu Bello. Kajian ini menggunakan kaedah soal selidik, wawancara secara spontan dan pemerhatian untuk pengumpulan data daripada mahasiswa yang dipilih secara rawak dari institusi tersebut melalui empat fakulti iaitu Fakulti Seni, Pendidikan, Kejuruteraan dan Sosial Sains. Penemuan menunjukkan bahawa mereka yang kebanyakannya dikecualikan daripada komunikasi dalam kumpulan subjek kajian ini melalui penggunaan perkataan slanga secara kod adalah pensyarah, pengawas peperiksaan dan pelajar wanita. Penemuan menunjukkan bahawa terdapat kelaziman dalam penggunaan slanga di kalangan pelajar-pelajar Universiti Ahmadu Bello, Zaria. Buktinya, $87.6 \%$ responden yang menggunakan slanga. Penganalisisan data membuktikan bahawa pelajar lelaki merupakan bilangan pengguna yang paling tinggi seperti yang ditunjukkan oleh $62.4 \%$ responden yang bersetuju dengan fakta ini berbanding dengan pelajar wanita hanya 37.6\%. Penemuan ini juga membuktikan bahawa, pelajar lelaki menggunakan lebih banyak slanga daripada pelajar wanita. Kajian ini menyimpulkan bahawa, slanga seperti yang digunakan oleh subjek kajian bukan sekadar simbol identiti, tetapi alat yang teguh dalam komunikasi mereka.

Berdasarkan sorotan kajian lepas ini, pengkaji ada menyatakan bahawa kajian-kajian lepas mengenai slanga secara umum, tetapi pengkaji juga mencari kajian lepas mengenai slanga yang ada mengaplikasikan teori Semantik Kognitif mahupun kajian lepas secara umum yang mengaplikasikan Kerangka Kategori Jaringan Radial tersebut. Berikutan perkara tersebut, reruang kelompangan kajian ini memberi peluang kepada pengkaji untuk menjalankan kajian bahasa slanga remaja Iban Sebuyau berpandukan Kategori Jaringan Radial (Lakoff, 1987). Kecenderungan memanifestasikan idea untuk mengkaji bahasa slanga yang diujarkan dalam kalangan remaja Iban Sebuyau, Sarawak menunjukkan bahawa masyarakat Iban juga menggunakan slanga dalam komunikasi harian khususnya golongan remaja.

\subsection{KERANGKA TEORI KATEGORI JARINGAN RADIAL}

George Lakoff merupakan tokoh yang mengasaskan teori ini pada tahun 1987. Teori ini mempunyai fokus utama dalam menerangkan entiti peluasan makna. Pendekatan ini juga memperlihatkan dua elemen yang penting dalam penghuraiannya, iaitu makna teras dan makna pinggirannya. Rajah 1 yang berikut memaparkan peluasan makna berdasarkan Kerangka Kategori Jaringan Radial:

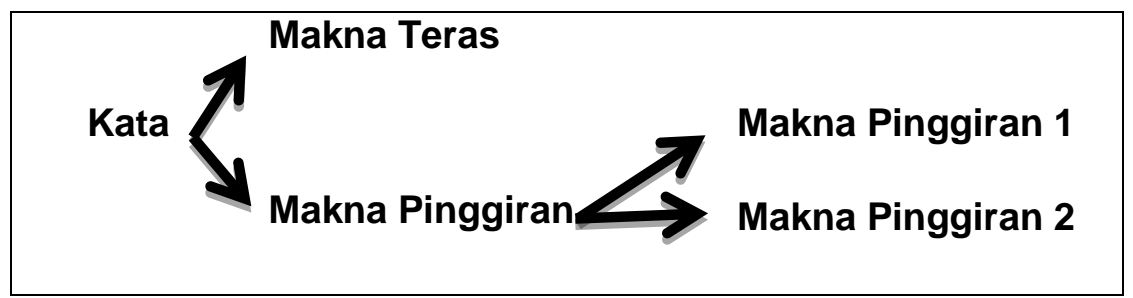

Rajah 1 Rajah Peluasan Makna Berdasarkan Kerangka Kategori Jaringan Radial

Makna teras sesuatu kata merujuk kepada makna asal, manakala makna pinggiran ialah makna lain yang diambil dengan merujuk kepada entiti sumber sesuatu kata, benda atau objek. Sarudin dan Jalaluddin (2017) pula menyatakan teori ini mengandungi bahagian teras, iaitu prototaip dan bahagian pinggiran ialah peluasan makna bagi entiti sumber tersebut. Tambahan lagi, model prototaip merupakan model pertama atau makna pertama untuk merujuk entiti sumber tersebut, manakala ahli pinggiran pula tidak terhad kepada satu makna pinggiran sahaja tetapi memiliki pelbagai makna pinggiran yang lain. Kerangka ini secara dasarnya menerangkan mengenai konsep peluasan makna sesuatu kata. Peluasan makna tersebut adalah berpandukan kepada motivasi, iaitu penjelasan mengenai erti pertama (prototaip) dan penghuraian tentang maksud kedua (makna pinggiran).

\subsection{METODOLOGI}

Penyelidikan ini merupakan kajian yang menerapkan kaedah kualitatif dengan mengumpulkan data bahasa slanga secara lapangan huluan. Omar (2015a) menyatakan bahawa kajian lapangan huluan adalah bersandarkan kepada bahasa, dialek dan komuniti penuturnya yang belum dikaji. Kajian lapangan huluan diaplikasikan dalam kajian ini kerana pengkaji memerlukan sumber data bahasa slanga yang agak terhad dijalankan di kawasan pedalaman daerah Sebuyau, Sarawak. Rasional kajian lapangan huluan ini menjadi panduan kerana kajian ini memfokus kepada komuniti Iban, data bahasa slanga dan kawasan pedalaman, iaitu Sebuyau, Sarawak. Selain itu, Omar (2015a) turut menegaskan bahawa penyelidikan jenis lapangan huluan ini memperoleh data dengan menggunakan kaedah menemu bual informan. Pemilihan kaedah kajian ini sesuai dengan pendapat yang disarankan oleh Samarin (1967) yang menyatakan bahawa setiap pemprosesan data adalah berdasarkan keselesaan pengkaji untuk memilih data yang sesuai dengan topik kajian pengkaji. Kaedah yang menjadi fokus utama dalam kajian ini ialah kaedah penyelidikan lapangan, iaitu pengkaji memperoleh data-data bahasa slanga remaja Iban Sebuyau, Sarawak melalui teknik temu bual secara mendalam. 
Teknik temu bual secara mendalam memerlukan pengkaji untuk mencatatkan butir penting yang dibangkitkan dalam interaksi tersebut. Pengkaji terlebih dahulu menerangkan konsep slanga dan tujuan kajian dibuat. Contohnya, pengkaji menanyakan soalan mengenai kata slanga yang digunakan di sekolah atau di kelompok tempat yang lain. Teknik rakaman semasa menemu bual informan juga digunakan sebagai rekod pengkaji. Butiran rakaman termasuklah nama informan, umur dan data slanga. Langkah seterusnya ialah pengkaji menentukan kawasan kajian. Pengkaji memilih kawasan pedalaman, iaitu daerah Sebuyau, Sarawak. Dalam laman rasmi Sarawak Government, Sebuyau merupakan subdaerah dalam kawasan Samarahan. Faktor pemilihan daerah Sebuyau ini sebagai kawasan kajian ini adalah untuk meneliti aspek slanga bahasa Iban Sebuyau kerana kurangnya kajian akademik yang meneliti fenomena bahasa dalam komuniti ini. Daerah Sebuyau juga majoritinya terdiri daripada perkampungan masyarakat Iban. Penduduknya berbangsa Iban juga memiliki fenomena kebahasaannya yang dapat dikaji dari sudut ilmiah, misalnya dalam kerangka Semantik. Selain itu, kemudahan mendapatkan data kajian mengenai slanga bahasa Iban juga antara faktor pemilihan kawasan ini memandangkan faktor lokasi yang mudah dilawat oleh pengkaji untuk mendapatkan data. Jadi, pengkaji lebih mudah untuk mendapatkan data kajian serta sumber-sumber daripada informan mengenai perkataan slanga yang digunakan oleh remaja di daerah tersebut. Antara lain, pengkaji memfokus kepada bahasa Iban dengan memilih kawasan terdekat, iaitu Sebuyau untuk melakukan penyelidikan.

Kemudian, pengkaji mendapatkan maklumat latar mengenai masyarakat tumpuan dalam kajian ini, iaitu pengetahuan tentang latar belakang masyarakat Iban di kawasan Sebuyau, Sarawak. Pengkaji memasuki kawasan kajian bagi mendapatkan kebenaran kepada ketua kaum untuk menjalankan penyelidikan. Prosedur seterusnya pula ialah pengkaji memilih 5 orang informan remaja lelaki dan 5 orang informan remaja perempuan untuk ditemu bual secara mendalam, iaitu berbangsa Iban yang terhad kepada daerah Sebuyau sahaja. Menurut UNICEF (2011), konsep "remaja" berumur antara 10 ke 19 tahun. Rasional pembahagian pemilihan informan tersebut adalah mengambil kira faktor keseimbangan data slanga yang digunakan dalam pertuturan harian mereka. Pemilihan informan ini turut berpandukan tahap kesihatan, penguasaan bahasa dan latar belakang agar data yang diperoleh lebih jelas dan terperinci. Data-data slanga yang telah dikumpulkan melalui temu bual akan ditranskripsikan atau diekstrak daripada rakaman pengkaji. Terdapat 15 kata slanga yang terdiri daripada kategori kata nama dan kata kerja dikumpulkan melalui informan tersebut. Walau bagaimanapun, dalam penulisan ini, pengkaji hanya menumpukan kepada tujuh data slanga dalam kategori kata kerja. Data bahasa slanga remaja Iban Sebuyau yang telah diperoleh akan dipersembahkan dalam bentuk jadual (lihat di Jadual 1). Rajah 2 berikut merupakan ringkasan bagi kaedah pengumpulan data dalam penyelidikan ini :

\begin{tabular}{|l|ll|}
\hline Kaedah & i. & Temu bual secara mendalam \\
Pengumpulan & ii. & Teknik rakaman \\
Data & iii. & Menentukan kawasan kajian \\
& iv. & Mendapatkan maklumat latar \\
& v. & Memasuki kawasan kajian \\
& vi. & Memilih informan \\
& vii. & Mengekstrak data \\
& viii. & Mengelaskan data \\
\hline
\end{tabular}

Rajah 2 Kaedah Pengumpulan Data

Dari sudut kaedah analisis data pula, data-data yang telah dikelaskan akan dihuraikan dengan menggunakan pendekatan Kerangka Kategori Jaringan Radial (Lakoff, 1987) bagi melihat peluasan makna yang berlaku dalam bahasa slanga remaja Iban Sebuyau. Perbincangan yang dipacu oleh pendekatan tersebut diterangkan dengan menggunakan contoh yang telah disesuaikan daripada kajian yang dijalankan oleh Baba (2002) mengenai perkataan "Ibu" :

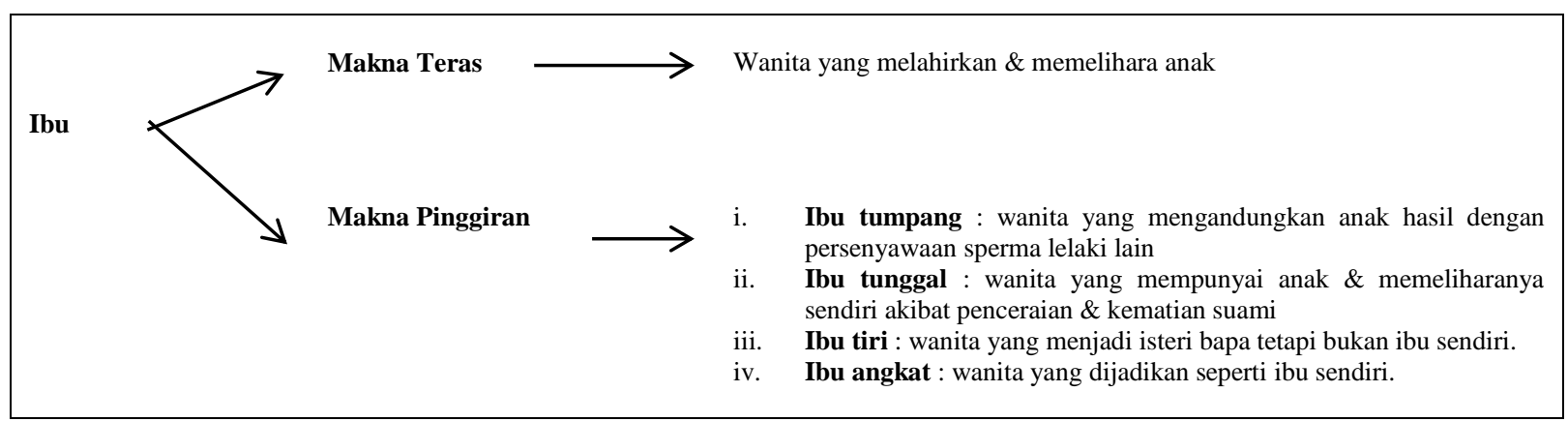

Rajah 3 Kaedah Analisis Data

Rajah 3 menunjukkan kata "ibu" itu sendiri merupakan makna prototaip sebelum kata "ibu" tersebut sebelum ditafsirkan kepada makna pinggiran. Makna pinggiran kata "ibu" tersebut wujud apabila digabungkan dengan kata yang lain untuk menunjukkan makna subkategori pinggiran seperti "ibu angkat", "ibu tunggal", "ibu tumpang", dan "ibu tiri". Keseluruhannya, kosa kata "Ibu" membawa pelbagai makna pinggiran yang diwujudkan berdasarkan konteks dan situasi. 


\subsection{DAPATAN DAN PERBINCANGAN}

Bahagian ini membincangkan bahasa slanga remaja Iban Sebuyau kategori kata kerja yang didapati mengalami peluasan makna. Berikut merupakan pemaparan data slanga remaja Iban Sebuyau (SRIS) :

Jadual 1 Senarai Data Bahasa Slanga Remaja Iban Sebuyau (Kata Kerja)

\begin{tabular}{|c|c|c|c|}
\hline Bil. & Kata B. Slanga Iban & Makna Teras (BM) & Makna Pinggiran (BIban) \\
\hline 1. & $\begin{array}{l}\text { Merueh (merus) } \\
\text { [mərujh] }\end{array}$ & Perbuatan memberus & Menasihati atau mengajar secara agresif \\
\hline 2. & $\begin{array}{l}\text { Ngaga'Peta } \\
\text { [yãga? pəta] }\end{array}$ & Membuat/melakar peta & Meliur semasa tidur \\
\hline 3. & $\begin{array}{l}\text { Ngangat Nyawa } \\
\text { [yãyãt j ãwã] }\end{array}$ & Menghangatkan rongga mulut & Minum-minum \\
\hline 4. & $\begin{array}{l}\text { Belagu } \\
\text { [bəlagu] }\end{array}$ & Bernyanyi & $\begin{array}{l}\text { Mengira kiraan mata dalam permainan } \\
\text { sepak takraw }\end{array}$ \\
\hline 5. & $\begin{array}{l}\text { Nunjuk Langit } \\
\text { [nũnj uək lanĩt] }\end{array}$ & Perbuatan menunjuk ke arah langit & Perbuatan menari \\
\hline 6. & $\begin{array}{l}\text { Melabur } \\
\text { [məlabuər] }\end{array}$ & $\begin{array}{c}\text { Meletakkan sejumlah wang untuk sesuatu usaha } \\
\text { dengan tujuan memperoleh keuntungan, menanam } \\
\text { modal }\end{array}$ & Membuang air besar \\
\hline 7. & $\begin{array}{l}\text { Fogging } \\
\text { [fogin] }\end{array}$ & Perbuatan menyembur asap & Merokok \\
\hline
\end{tabular}

\section{i. $\quad$ Merueh [mərujh] (memberus)}

Secara amnya, perkataan merueh merupakan perkataan yang berasal dari kata dasar merus atau dalam bahasa Melayunya, memberus. Perubahan fonem -ueh daripada -us antara cabang dialek-dialek bahasa Iban Sebuyau. Berdasarkan Bup Sereba Reti jaku Iban (2011), leksikal berus atau merus ini merujuk kepada kereban tukang ti' nguna bulu dikena' nyapu chat tauka gerenis ramu enggau ti bukai (peralatan pertukangan yang menggunakan bulu untuk menyapu warna atau syelek papan). Selain itu, memberus ditakrifkan sebagai membersihkan dengan berus (Kamus Dewan Edisi Keempat, 2015). Pendefinisian yang diberikan oleh kedua-dua kamus tersebut tidak jauh berbeza, iaitu digunakan untuk menyapu atau membersihkan. Penggunaan perkataan merueh melalui makna teras adalah seperti contoh yang berikut:

Contoh 1:

'Kemari', aku baru udah tembu' merueh gelegar ba' mua rumah nya. Saritu, merueh (merus) perau' apai aku ga. Nyau nadai berenti pengawa merueh ku tu. Tang, nadai ngawa. Menyadik aku bisi nyaup aku merueh utai nya." ko Luping madah ngagai Empaling.

(Terjemahan BMS: "Semalam, saya baru dah habis memberus buluh di hadapan rumah itu. Hari ini,

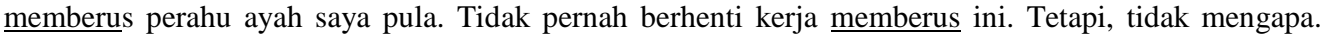
Adik saya juga membantu memberus semua benda tu." beritahu Luping kepada Empaling.

Ayat dalam contoh 1 tersebut memaparkan fungsi leksikal merueh sebagai kata kerja sebagai satu perbuatan menggeserkan berus pada sesuatu objek agar kelihatan bersih. Meskipun kata dasar untuk bahasa Iban standard ialah merus, tetapi maknanya tetap sama, perbezaan yang dapat dilihat hanya melibatkan bunyi pada hujung kata, iaitu pada segmen fonem belakang iaitu -ueh daripada -us. Dalam ayat tersebut, kata kerja merueh menerangkan perbuatan menyapu atau membersihkan sesuatu objek. Sehubungan dengan itu, merueh menjadi inti sebagai frasa kerja dalam binaan ayat tersebut. Tetapi, penggunaan leksikal merueh dalam slanga remaja Iban Sebuyau pula dimaksudkan sebagai satu perbuatan menasihati atau memberi ajaran secara agresif kepada seseorang yang degil, ingkar atau bersikap melawan khususnya kepada remaja atau kanak-kanak dalam kelompok remaja Iban Sebuyau. Informan 9 menyatakan dalam situasi ini, individu yang degil akan di ajar dengan secukupnya untuk menimbulkan kesedaran dalam dirinya. Contoh-contoh penggunaan kata ini dalam slanga remaja Iban Sebuyau adalah seperti berikut:

Jadual 2 Penggunaan kata merueh (merus) dalam SRIS

\begin{tabular}{|c|c|c|}
\hline Data & SRIS & Terjemahan Dalam BMS \\
\hline Contoh 2 & $\begin{array}{l}\text { Nembiak nya' nya' tau kena' berueh (berus), laban } \\
\text { nadai ngasi ke ajar menyadik iya. }\end{array}$ & $\begin{array}{l}\text { Budak tu memang patut di ajar, sebab dia tak pernah } \\
\text { mendengar nasihat abang dia. }\end{array}$ \\
\hline Contoh 3 & Uji dik merueh (merus) iya. Aku enda berani. & Cuba kau menasihati dia. Saya tak berani. \\
\hline
\end{tabular}

Berdasarkan ayat dalam Jadual 2, data kajian merueh (merus) tidak lagi digunakan untuk merujuk perbuatan membersihkan atau menyapu sesuatu yang konkrit, tetapi digunakan untuk merujuk kepada makna menasihati seseorang. Jadi, dari penciptaan makna kepada perbuatan yang nyata, slanga merueh berubah maknanya kepada sesuatu yang abstrak. Dalam slanga remaja Iban Sebuyau, situasi penggunaan perkataan ini adalah untuk menasihati seseorang terutamanya remaja. Peluasan makna mengenai slanga merueh dalam konteks remaja Iban Sebuyau ditunjukkan seperti rajah yang berikut: 


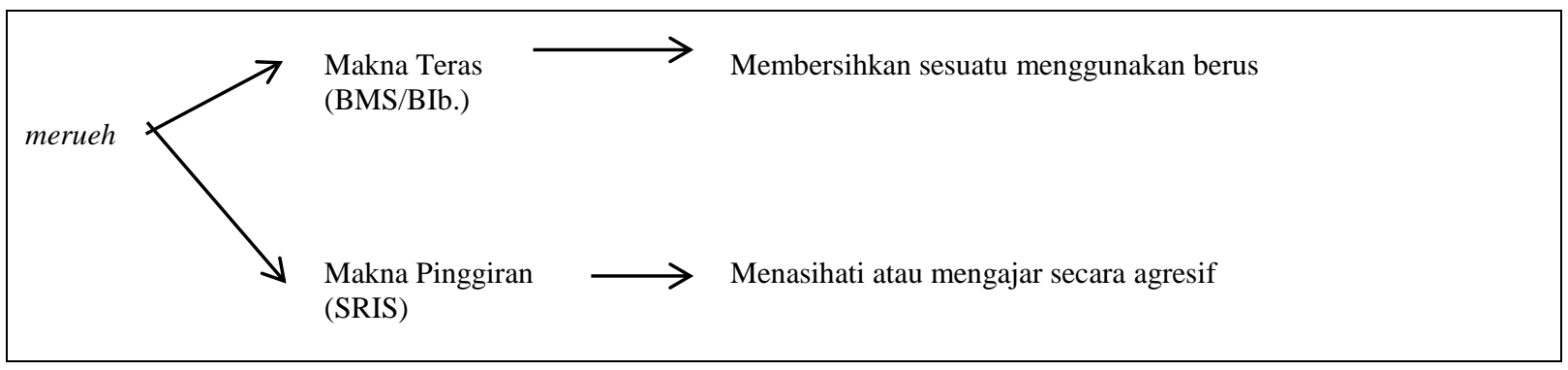

Rajah 4: Peluasan makna merueh dalam SRIS

Berdasarkan pecahan makna (makna teras dan pinggiran) melalui Kerangka Kategori Jaringan Radial dalam Rajah 4, dapat dikatakan bahawa peluasan makna ini mengambil kira ciri-ciri perbuatan memberus untuk diciptakan makna menasihati atau mengajar dalam slanga remaja Iban Sebuyau. Perbuatan memberus pada sesuatu ini berkait rapat dengan perbuatan memberi ajaran secara secukupnya, misalnya memberus pakaian untuk kelihatan bersih dan membuang kotoran, begitu juga dengan sifat menasihati seseorang untuk menyedarkan umpama membuang sifat buruk dalam diri individu yang ingkar itu. Contohnya, kita melihat kepada konteks berus yang mempunyai fizikal yang tajam dan perbuatan memberus itu yang boleh menyebabkan kelukaan atau kerosakan pada bahagian yang lembut seperti tangan, kain dan sebagainya.

\section{ii. Ngaga' Peta [yãga? pota]}

Menurut Bup Sereba Reti Jaku Iban (2011), ngaga bermaksud ngereja pengawa ti bisi mansutka asil (melakukan sesuatu pekerjaan yang mendatangkan hasil) yang terbit daripada kata dasar gaga' (buat). Kata slanga peta pula merupakan kata pinjaman daripada bahasa Melayu, iaitu 'peta' yang bermaksud lukisan (gambar) pada kertas dan lain-lain yang menunjukkan kedudukan negeri, sungai, gunung, dan lain-lain (Kamus Dewan Edisi Keempat, 2015). Terdapat beberapa komponen yang digunakan dalam pemetaan, iaitu kontur, garisan longitud dan latitud, arah angin, dan sebagainya. Contoh berikut menunjukkan penggunaan perkataan ngaga dan peta masing-masing dalam bahasa Melayu standard dan bahasa Iban:

Contoh 4: Jika pandangan sebegini diterima, negara Malaysia sebagai sebuah negara bangsa mungkin tidak dapat bertahan dan wujud dalam peta dunia (Baharuddin, 2012).

Contoh 5: $\quad$ Anang ngaga ulah ti enda menuku (Majalah Pegari, 2013).

(Terjemahan BMS: Jangan buat perkara yang tidak senonoh)

Contoh 4 dan 5 memperlihatkan penggunaan kata nama peta yang berfungsi kata inti untuk frasa nama yang berfungsi pada subjek binaan ayat tersebut, manakala kata kerja ngaga dalam bahasa Iban merupakan kata inti frasa kerja yang berfungsi dalam predikat ayat bagi contoh 5. Omar (2015b) mengkategorikan kata kerja 'buat'(ngaga) sebagai subkategori kata kerja yang mendukung perbuatan yang dilakukan untuk menghasilkan sesuatu, manakala kata nama peta ini disifatkan sebagai kata nama yang mendukung objek atau sesuatu yang konkrit boleh dilihat dan nyata. Frasa ngaga' peta dalam slanga remaja Iban Sebuyau pula merupakan gabungan dua perkataan bahasa Iban dan Melayu iaitu ngaga' dan peta. Walau bagaimanapun, makna slanga ngaga' peta yang digunakan oleh remaja Iban Sebuyau bermaksud satu perbuatan yang melelehkan air liur semasa tidur (Informan 10). Merujuk kepada bentuk peta, lakarannya bersifat tidak sekata di kedudukan bumi atau glob bumi. Sifat-sifat bentuk peta itu sendiri menyerupai liur ketika dilihat di atas bantal semasa bangun dari tidur. Bukan itu sahaja, terdapat juga konsep lain yang menggunakan kata terbitan ini untuk merujuk panau (kurap air) melalui perkataan berpeta. Contoh berikut menunjukkan penggunaan frasa ngaga' peta dalam slanga remaja Iban Sebuyau:

Jadual 3 Penggunaan kata ngaga' peta dalam SRIS

\begin{tabular}{|l|l|l|}
\hline Data & SRIS & Terjemahan Dalam BMS \\
\hline Contoh 6 & $\begin{array}{l}\text { Asal Jabing tinduk, jarang enda' iya tu' ngaga' } \\
\text { peta. }\end{array}$ & $\begin{array}{l}\text { Kalau Jabing tidur, memang tidak pernah tidak dia meliur } \\
\text { semasa tidur. }\end{array}$ \\
\hline Contoh 7 & $\begin{array}{l}\text { Rindu' ku meda nembiak nya' tinduk, nadai tesat } \\
\text { iya. Laban udah ngaga'peta. }\end{array}$ & $\begin{array}{l}\text { Terhibur saya melihat budak itu tidur, tidak akan sesat dia. } \\
\text { Sebab sudah meliur semasa tidur. }\end{array}$ \\
\hline
\end{tabular}

Jadual 3 memaparkan penggunaan data ngaga' peta dalam contoh 6 dan 7. Kedua-dua ayat tersebut digunakan dalam pergaulan seharian yang jenaka untuk memperli individu yang suka meliur semasa tidur. Dalam konteks tersebut, individu yang sebegitu sering kali mengungkapkan frasa ngaga' peta sekali agar makna yang ingin disampaikan difahami oleh kelompok remaja ini. Jika frasa tersebut menyingkirkan salah satu kata, misalnya perkataan ngaga', maka tidak wujudlah slanga untuk merujuk perbuatan melelehkan air liur 
semasa tidur. Peluasan makna yang diberikan oleh slanga remaja Iban Sebuyau bagi frasa ngaga' peta dapat dilihat melalui pendekatan Kerangka Kategori Jaringan Radial:

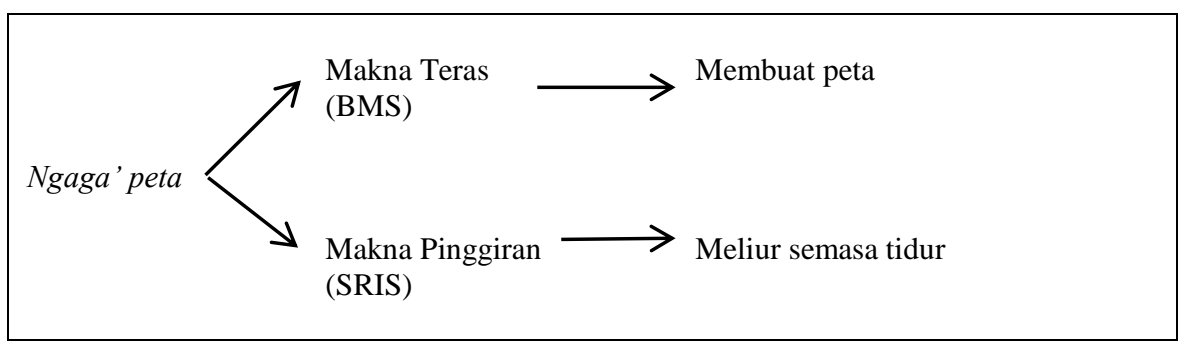

Rajah 5 Peluasan makna ngaga' peta dalam SRIS

Melihat kepada peluasan makna yang ditunjukkan oleh Kerangka Kategori Jaringan Radial dalam Rajah 5, peluasan makna tersebut mengambil sifat fizikal yang dimiliki oleh lakaran bentuk peta tersebut. Sesuai dengan pemaknaan mengenai bentuk 'air liur' semasa dalam proses tidur, maka penciptaan makna tersebut berasaskan bentuk peta tersebut. Kreativiti remaja tentang pemaknaan sifat air liur tersebut diilhamkan melalui corak atau bentuk 'peta' itu ketika ia sudah kering yang timbul di pelapik kain bantal atau tilam. Konteks penggunaan perkataan ini digunakan sebagai jenaka dalam kelompok sosial remaja Iban Sebuyau.

\section{iii. $\quad$ Ngangat Nyawa [yãyãt j ãwã]}

Ngangat dalam makna kamus ialah panas api tauka matahari, bisa asai, pedas (ngangat) atau dalam bahasa Melayu standard, panas bahang api atau matahari, atau rasa pedas, manakala nyawa ialah lubang ba' mua alai ngunyah pemakai (bahagian organ artikulasi yang terdapat di muka manusia yang digunakan untuk mengunyah makanan) (Bup Sereba Reti Jaku Iban, 2011). Jika digabungkan kedua-dua kata tersebut, maka makna teras berdasarkan pendefinisian ialah memanaskan mulut yang merupakan gabungan dua kata yang berlainan seperti yang dinyatakan dalam pendefinisan oleh kamus Iban. Contoh penggunaan kata ngangat dan nyawa dalam bahasa Iban. dapat dilihat seperti yang berikut:

Contoh 8: $\quad$ Anang ka nguji nurah nyawa ngena ai angat, uji irup ke ai celap. Jampat agi mulut dik ka gerai. Anang medis kediri ngena ai angat.

(Terjemahan: Jangan cuba nak minum air panas, minumlah air sejuk. Cepat lagi mulut kau tu sembuh.

Jangan nak susahkan diri minum air panas)

Jika dilihat contoh 8, frasa ngangat nyawa tidak dapat bergabung dalam satu frasa yang sama kerana kedua-dua kata berlainan sifat tabii. Ngangat merupakan satu perbuatan, manakala nyawa merupakan keseluruhan bahagian dalam mulut. Makna literal bagi frasa ngangat nyawa agak terhad dan berlainan untuk menunjukkan konsep secara literal sebagai perbuatan 'memanaskan rongga mulut'. Berlainan pula dengan slanga remaja Iban Sebuyau, frasa ngangat nyawa digunakan untuk merujuk kepada perlakuan seseorang dalam konteks makan-minum (Informan 3). Frasa ngangat nyawa ini lazimnya digunakan ketika waktu pagi sebelum memulakan pekerjaan dan persekolahan dalam golongan remaja Iban Sebuyau. Contoh yang berikut menunjukkan penggunaan frasa ngangat nyawa dalam konteks slanga remaja Iban Sebuyau:

Jadual 4 ngangat nyawa dalam SRIS

\begin{tabular}{|l|l|l|}
\hline Data & SRIS & Terjemahan Dalam BMS \\
\hline Contoh 9 & Aram tua ngangat nyawa pagi tu. & Mari kita minum dulu pagi ini. \\
\hline Contoh 10 & Sebedau gawa, ngangat nyawa dulu. & Sebelum bekerja, minum pagi dulu. \\
\hline
\end{tabular}

Berdasarkan Jadual 4, contoh 9 dan 10 mempamerkan penggunaan frasa ngangat nyawa dalam slanga remaja Iban Sebuyau. Perubahan makna ini agak berbeza dengan makna yang asal, iaitu 'memanaskan alat artikulasi'. Kebudayaan kelompok remaja memberi pentafsiran yang berbeza bagi frasa ini. Walaupun dilihat agak berbeza yang ketara, tetapi kreativiti remaja menghasilkan makna tersebut unjuran daripada cecair (air minuman) yang lazimnya panas atau suam memasuki rongga mulut telah memberi ilham kepada mereka untuk memberi makna ngangat nyawa sebagai sarapan. Pendekatan Kerangka Kategori Jaringan Radial membantu memperlihatkan pola peluasan makna bagi frasa ngangat nyawa: 


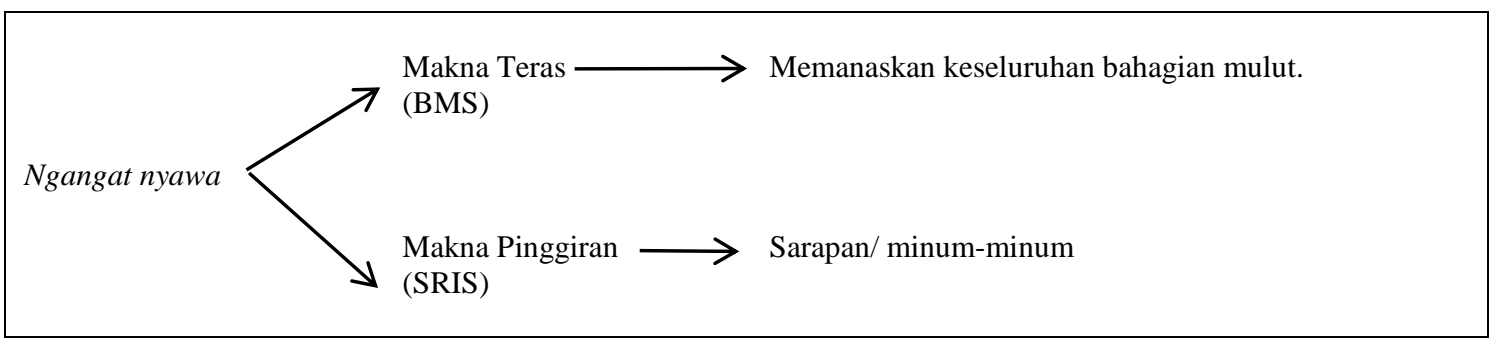

Rajah 6 Peluasan makna ngangat nyawa dalam SRIS

Kerangka Kategori Jaringan Radial dalam Rajah 6 menunjukkan perubahan makna frasa ngangat nyawa. Budaya pertuturan remaja Iban Sebuyau menunjukkan kata slanga ngangat nyawa dituturkan ketika sarapan. Informan 3 juga mengatakan bahawa kata slanga ini berupa simbolik untuk menyatakan perbuatan minum air kopi, susu, teh, atau sesuatu air yang suam sebelum memulakan pembelajaran atau kerja. Penggunaan slanga ini difahami oleh remaja Iban Sebuyau yang menuturkannya kerana kita jarang melihat seseorang minum air sejuk ketika waktu pagi.

\section{iv. Belagu [bəlagu]}

Kata terbitan belagu dalam bahasa Iban ini diterbitkan daripada kata dasar 'lagu' yang bermaksud leka main ti' disebut enggau patah sura ti' manah ti' tau' ngerindu' ka ati peninga yang bermaksud sejenis lontaran suara yang digunakan untuk mendendangkan hati yang dapat mempengaruhi pendengar (Bup Sereba Reti Jaku Iban, 2011). Lagu menjadi wahana untuk seseorang menzahirkan perasaan yang berupa bentuk tulisan sesuatu yang ingin disampaikan itu dapat dibaca dan difahami oleh pendengar atau pembaca (Mohd. Ali \& Abd. Rahim, 2011). Lagu juga boleh dikategorikan sebagai puisi. Contoh ayat dengan penggunaan kata belagu yang diperoleh daripada Informan 4 adalah seperti berikut:

Contoh 11: $\quad$ Kemari bisi bepekit belagu ba rumah panjai sida Renting. Ya ti lumor satu belagu demalam datai ari Lubok Antu. Pengawa belagu tu udah diatur komiti rumah panjai Renting segulai enggau Wai Fm RTM Kuching.

(Terjemahan: Semalam ada pertandingan menyanyi di Rumah Panjang Renting. Johan bernyanyi, iaitu dari Lubok Antu. Aktiviti menyanyi ini dianjurkan bersama Rumah Panjang Renting dan Wai Fm RTM Kuching.

Ayat yang ditunjukkan dalam contoh 11 menunjukkan fungsi kata kerja belagu dalam binaan ayat yang menjadi frasa kerja untuk menerangkan perkara yang berlaku dalam predikat tersebut. Sememangnya makna asal untuk belagu ini merupakan perbuatan menyanyikan sesuatu dengan iringan muzik, nyanyian tradisional atau moden. Sebaliknya, pentafsiran makna belagu ini sebagai bernyanyi telah berubah kepada perbuatan mengira kiraan mata dalam situasi permainan sepak takraw (Informan 7). Konsep ini sama juga melibatkan lontaran suara, cuma dibezakan oleh domain masing-masing seperti bernyanyi digunakan semasa persembahan untuk menyampaikan makna lagu. Tetapi, dalam slanga remaja Iban Sebuyau, belagu digunakan untuk menghitung kiraan mata bagi kedua-dua pasukan yang bermain sepak takraw. Berikut merupakan contoh bagi kata slanga belagu dalam kalangan remaja Iban Sebuyau:

Jadual 5 Penggunaan kata belagu dalam SRIS

\begin{tabular}{|l|l|l|}
\hline Data & SRIS & Terjemahan Dalam BMS \\
\hline Contoh 12 & $\begin{array}{l}\text { Dik belagu ke kitai Dom. Lagi aku ngambi bol } \\
\text { takraw. }\end{array}$ & Kau mengira untuk kita Dom. Nanti saya ambil bola takraw. \\
\hline Contoh 13 & \begin{tabular}{l} 
Sapa belagu udah tok? Tim kami main dulu. \\
\hline
\end{tabular} & Siapa yang mengira selepas ini? Pasukan kami bermain dulu. \\
\hline
\end{tabular}

Contoh yang ditunjukkan dalam Jadual 5 menunjukkan makna teras belagu bukan lagi untuk merujuk bernyanyi, tetapi merujuk kepada pengiraan mata permainan sepak takraw. Dalam konteks slanga remaja Iban Sebuyau, jarang sekali leksikal pinggiran ini digunakan dalam konteks yang lain. Tahap penciptaan makna ini melihat kepada individu yang mengira atau sebagai pengadil perlawanan tersebut dianggap sebagai pengira untuk menentukan mata yang diperoleh. Untuk melihat peluasan makna kata belagu, model Kerangka Kategori Jaringan Radial membincangkan perubahan makna tersebut: 


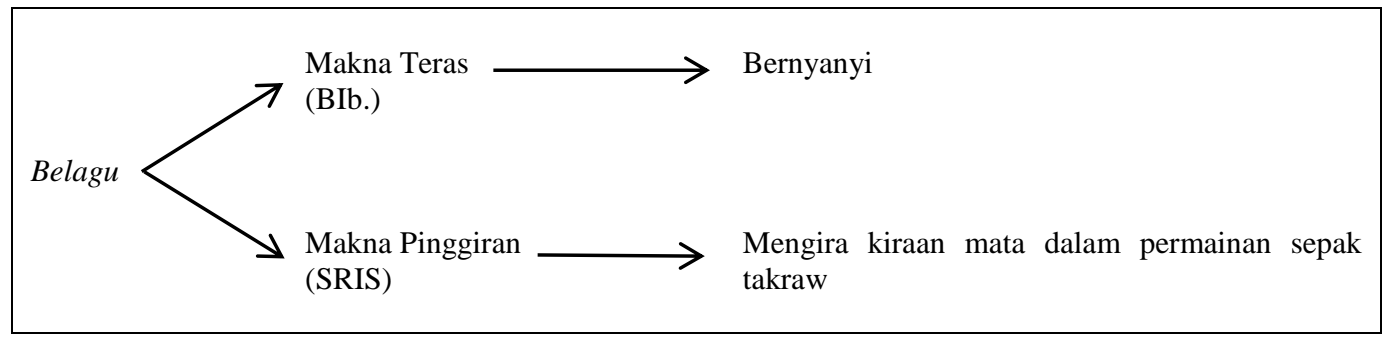

Rajah 7 Peluasan makna belagu dalam SRIS

Makna berdasarkan model Kerangka Kategori Jaringan Radial dalam Rajah 7 menjelaskan tentang makna belagu pada asalnya sebagai perbuatan bernyanyi, tetapi ia berubah kepada mengira kiraan mata dalam slanga remaja Iban Sebuyau. Perubahan ini masih mengekalkan kreativiti yang sama, iaitu melontarkan suara sebagaimana perbuatan mengira masih menggunakan suara dan bernyanyi juga menggunakan domain suara. Peluasan makna kata slanga belagu ini juga didorong oleh kognitif remaja Iban Sebuyau yang memperlihatkan pengiraan mata (pengadil) bagi permainan ini yang menguasai atau pihak yang berhak menentukan mata dalam perlawanan sepak takraw tersebut. Fenomena ini umpama seorang penyanyi yang menguasai pentas untuk sesuatu upacara yang diberi perhatian bagi sesuatu tujuan seperti pertandingan atau hiburan. Jadi, kata slanga belagu ini mempunyai makna pinggiran selain daripada bernyanyi, iaitu pengiraan mata dalam sukan sepak takraw.

\section{v. $\quad$ Nunjuk Langit [nũnǰ uək lanit]}

Frasa nunjuk langit dalam bahasa Melayu standard merupakan 'menunjuk langit'. 'Menunjuk' ialah satu perbuatan mengarahkan jari telunjuk ke sesuatu tempat, memberitahu dengan isyarat, mengarahkan jari ke atas, menentukan, dan mengemukakan sesuatu sebagai alasan (Kamus Dewan Edisi Keempat, 2015). 'Langit' pula ditakrifkan sebagai lengkung yang tampaknya biru dan melingkungi bumi (Kamus Dewan Edisi Keempat, 2015). Contoh berikut merupakan penggunaan kata 'menunjuk' dan 'langit' dalam bahasa Melayu standard:

Contoh 14: Semasa pembubaran berlaku dalam Persatuan Pengakap Sekolah Menengah Kebangsaan Sebuyau, majoriti ahli-ahli pengakap_menunjuk Shahrul sebagai penyandang jawatan baharu pengerusi persatuan itu.

Contoh 15: $\quad$ Disangkakan langit itu rendah, dipandang dekat, dicapai tidak boleh.

Berdasarkan contoh 14, penggunaan kata 'menunjuk' dalam bahasa Melayu standard merujuk kepada 'menentukan orang yang dipilih'. Makna literal bagi contoh ini berbeza kerana digunakan dalam konteks memilih 'seseorang'. Contoh 15 pula mempamerkan kata 'langit' dalam bahasa Melayu berfungsi sebagai kata nama untuk menerangkan sesuatu yang dapat dilihat, berwarna biru dan melingkungi bumi. Selain itu, bahasa Iban. mempunyai frasa nunjuk langit ini. Menurut Bup Sereba Reti Jaku Iban (2011), langit merupakan kata nama yang mendukung maksud lapisan angin yang paling tinggi yang melindungi semua tempat di atas bumi dan berwarna biru, manakala nunjuk terbit daripada kata dasar tunjuk yang bermaksud madahka penunga (memberitahu arah). Jadi, gabungan kedua-dua leksikal tersebut menerbitkan makna memberitahu arah langit dengan menggunakan tunjuk jari yang juga menunjukkan ke arah atas. Penggunaan frasa nunjuk langit dapat dilihat melalui contoh yang berikut:

Contoh 16: $\quad$ Keno ko jerita kelia, enti anak raja benung ba atas remang, kitai enda tau nunjuk langit, enggaika kena jari singkong.

(Terjemahan: Menurut cerita orang dahulu, jika pelangi di atas langit, kita tidak dibenarkan untuk menunjuk ke langit, dikhuatirkan akan cacat tangan.

Tetapi, makna bagi frasa nunjuk langit dalam slanga remaja Iban Sebuyau adalah berbeza dengan makna yang tersurat atau makna yang diperoleh melalui kamus. Bagi Informan 2, makna tersirat dalam slanga remaja Iban Sebuyau bagi frasa nunjuk langit ialah perbuatan menari. Golongan remaja Iban Sebuyau menganggap frasa nunjuk langit ini sebagai sesuatu perbuatan menari kerana ketika mereka menari, secara automatik golongan ini menggunakan gaya mengangkat tunjuk jari ke atas sebagai tanda gembira. Biasanya, frasa ini digunakan ketika sesuatu perayaan berlangsung seperti Hari Gawai, majlis perkahwinan atau pertandingan bernyanyi. Contoh ayat yang berikut menunjukkan penggunaan frasa nunjuk langit dalam slanga remaja Iban Sebuyau:

Jadual 6 Penggunaan kata nunjuk langit dalam SRIS

\begin{tabular}{|l|l|l|}
\hline Data & SRIS & Terjemahan Dalam BMS \\
\hline Contoh 17 & Nadai nunjuk langit saritu pok? & Tidak menarikah hari ini? \\
\hline Contoh 18 & $\begin{array}{l}\text { Malam pagila bisi urang nikah. Amai-amai nunjuk } \\
\text { langit tu ila. }\end{array}$ & $\begin{array}{l}\text { Malam esok ada majlis perkahwinan. Menari sepuas-puasnya } \\
\text { nanti. }\end{array}$ \\
\hline
\end{tabular}


Jadual 6 memperlihatkan fungsi ayat yang menggunakan frasa nunjuk langit dalam slanga remaja Iban Sebuyau. Berdasarkan binaan ayat dalam contoh 17 dan 18, dapat dikatakan bahawa perubahan makna ini amat ketara daripada makna terasnya. Kefahaman tentang frasa nunjuk langit berdasarkan kedua-dua contoh tersebut memperlihatkan satu domain yang sangat jauh, misalnya makna teras nunjuk langit hanyalah satu perbuatan yang disifatkan sangat bersahaja jika dibandingkan dengan makna pinggiran yang menggerakkan seluruh badan untuk mencapai kefahaman tentang makna pinggiran itu. Gerak tari yang menggunakan tangan yang menggunakan gaya seseorang menunjuk jari ke atas telah mengilhamkan golongan remaja Iban Sebuyau untuk menghasilkan makna yang baharu ini. Teori Kerangka Kategori Jaringan Radial akan menerangkan peluasan makna nunjuk langit dalam slanga remaja Iban Sebuyau:

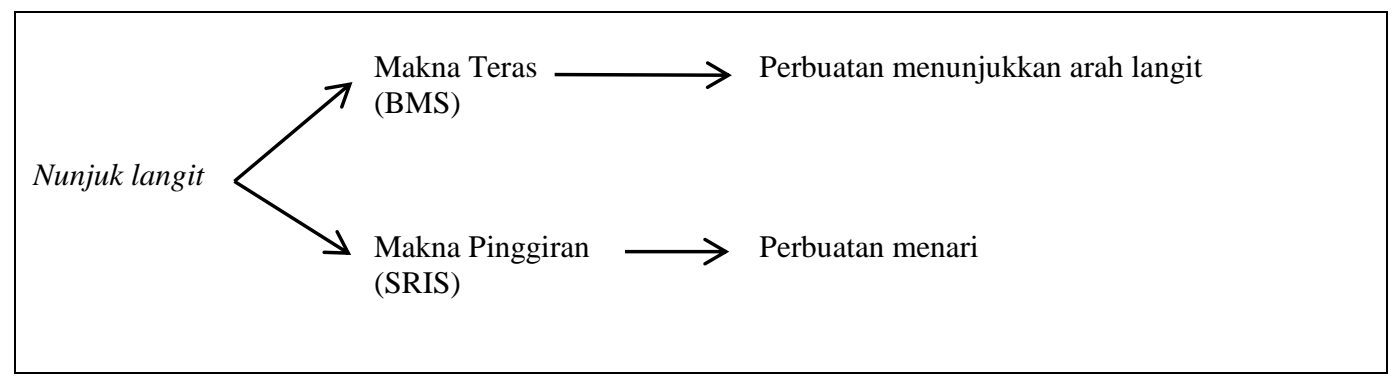

Rajah 8 Peluasan makna nunjuk langit dalam SRIS

Pendekatan Kerangka Kategori Jaringan Radial pada Rajah 8 menjelaskan perubahan makna bagi frasa nunjuk langit dalam slanga remaja Iban Sebuyau. Peluasan makna yang berlaku bagi frasa nunjuk langit melibatkan perkaitan budaya tarian bagi golongan remaja Iban Sebuyau. Tafsiran makna yang dihasilkan jika diteliti melalui teori Kerangka Kategori Jaringan Radial memperlihatkan remaja menyesuaikan konsep ini dengan sesuatu pergerakan atau tarian remaja tersebut. Hal ini bertepatan dengan pendapat Sariyan (2007) yang menyatakan bahawa penggunaan bahasa manusia bebas daripada kawalan rangsangan dan tidak semata-mata untuk fungsi komunikatif, tetapi lebih sebagai alat penyataan pemikiran dan sebagai gerak balas yang tepat kepada situasi baru. Ringkasnya, penggunaan kata slanga dicipta berdasarkan sesuatu peristiwa yang dilihat bagi memerikan sesuatu kata tersebut.

\section{vi. Melabur [məlabuər]}

Perkataan 'melabur' diterbitkan daripada kata dasar 'labur' yang bermaksud membekalkan makanan, wang, modal dan lain-lain atau meletakkan, memberikan, menyerahkan sejumlah wang untuk sesuatu usaha seperti pengeluaran barangan, perniagaan dan sebagainya dengan tujuan menanam modal (Kamus Dewan Edisi Keempat, 2015). Dalam pada itu, perbuatan 'melabur' sesuatu ini mampu menguntungkan sesebuah firma perniagaan atau individu yang memberi pulangan dividen dalam bentuk wang, makanan atau kebajikan kendiri. Pelaburan modal menjadi satu trend bagi individu atau peniaga untuk mengembangkan perniagaan atau menambahkan pendapatan sama ada pada peringkat domestik atau antarabangsa. Lazimnya, pelaburan ini diuruskan oleh institusi atau organisasi yang mengumpul dana daripada individu yang melabur dalam sesebuah pasaran saham. Contoh berikut menunjukkan penggunaan kata 'melabur' dalam bahasa Melayu :

Contoh 19: $\quad$ Ali melabur modal untuk meningkatkan keuntungan kedai runcitnya.

Contoh 20: $\quad$ Syarikat dari luar negara gemar untuk melabur modalnya di negara lain.

Kedua-dua contoh 19 dan 20 menunjukkan peranan kata terbitan tersebut sebagai kata kerja. Leksikal 'melabur' dalam contoh berikut menerangkan perbuatan melaburkan modal sebagai strategi domestik (contoh 19) dan antarabangsa (contoh 20). Makna leksikal yang dipaparkan menerusi contoh 4 dan 5 hanya memberi pemahaman yang berada dalam pemikiran pembaca, iaitu melaburkan sesuatu seperti duit. Dari aspek bahasa slanga remaja Iban Sebuyau, Informan 4 menyatakan entri kata 'melabur' telah diluaskan maknanya kepada satu perbuatan membuang bahan kumbahan daripada badan. Ringkasnya, makna pinggiran leksikal 'melabur' ini digunakan untuk merujuk perbuatan membuang air besar. Berbeza dengan makna yang sebenar, iaitu menyerahkan sejumlah wang untuk sesuatu usaha, perkaitan makna ini disebabkan perbuatan 'mengeluarkan sesuatu' atau sesuatu yang perkara yang kepunyaan kita diberikan kepada orang lain. Dalam komunikasi antara remaja Iban Sebuyau berkenaan mungkin kata ini bersifat kiasan bagi kelompok sosial remaja. Berdasarkan Informan 5, penggunaan kiasan perkataan 'melabur' dalam budaya Iban disifatkan sebagai budaya yang tidak berterus terang serta kekreatifan pengguna bahasa untuk memanipulasi sifat dalaman manusia. Berikut merupakan contoh untuk memahami makna perkataan 'melabur' dalam slanga remaja Iban Sebuyau:

Jadual 7 Penggunaan kata 'melabur' dalam SRIS

\begin{tabular}{|l|l|l|}
\hline Data & SRIS & Terjemahan Dalam BMS \\
\hline Contoh 21 & Aku udah melabur tadi. & Saya sudah membuang air besar tadi. \\
\hline Contoh 22 & Jabuh melabur ba jamban sepiak nyin tadi. & Jabuh membuang air besar di tandas sebelah itu tadi. \\
\hline
\end{tabular}


Berdasarkan data Jadual 7 dalam contoh 21 dan 22, kata slanga 'melabur' bukan lagi digunakan untuk merujuk mengeluarkan atau menyerahkan sejumlah wang untuk sesuatu usaha tetapi telah berubah kepada takrifan membuang air besar. Perbuatan mengeluarkan itu sendiri telah merujuk kepada konsep mengeluarkan modal walaupun berbeza dengan slanga remaja tersebut untuk merujuk perbuatan mengeluarkan bahan buangan daripada badan manusia. Model Kerangka Kategori Jaringan Radial menerangkan peluasan makna bagi kata slanga 'melabur' dalam slanga remaja Iban Sebuyau:

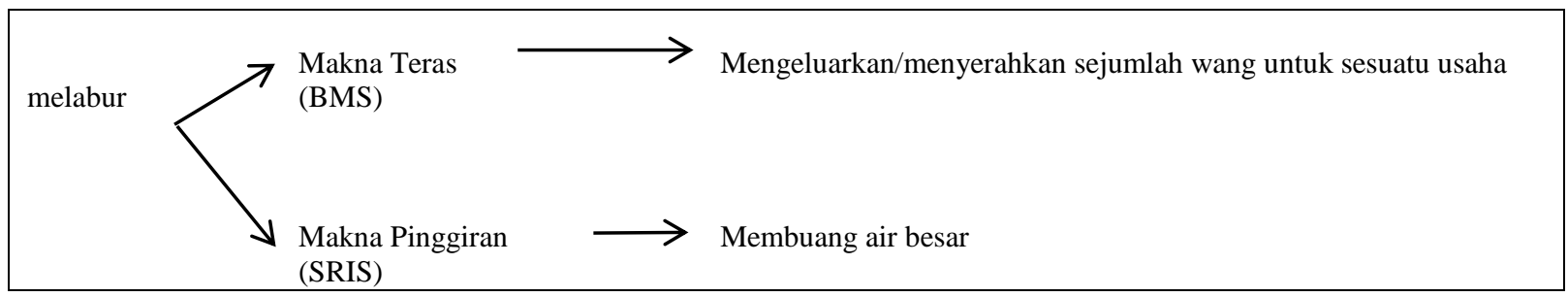

Rajah 9 Peluasan makna 'melabur' dalam SRIS

Peluasan makna yang ditunjukkan dalam Rajah 9 memperlihatkan perubahan makna teras, iaitu mengeluarkan atau menyerahkan sejumlah wang untuk sesuatu usaha kepada makna pinggiran, iaitu membuang air besar dalam slanga remaja Iban Sebuyau. Berdasarkan kata kunci yang ditunjuk melalui pemaknaan teras dan pinggiran, kedua-dua makna tersebut masih mengekalkan kata inti yang utama, iaitu 'membuang' dan 'mengeluarkan'. Antara lain, 'melabur' dirujuk sebagai slanga dalam konteks remaja Iban Sebuyau disebabkan individu tersebut ingin merahsiakan makna sebenar yang hanya dituturkan dalam kalangan kumpulan mereka sendiri. Jika dilihat pada kajian Subet dan Daud (2017), slanga pelacur bagi leksikal "servis' tidak lagi dirujuk sebagai perkhidmatan memperbaiki barang, tetapi dikembangkan maknanya menjadi pakej yang disyorkan untuk melanggan pelacur. Jadi, hanya kelompok sosial yang tertentu memahami penggunaan kosa kata slanga tersebut.

\section{vii. Fogging [fogin]}

Kata fogging diterbitkan daripada perkataan fog yang bermaksud 'kabus' (Kamus Dwibahasa Oxford Fajar, 2008). Jikalau dilihat penciptaan makna slanga tersebut, ia berkaitan dengan mesin penyembur atau fogging machine yang digunakan untuk menghalau pembiakan nyamuk di persekitaran bangunan, parit dan tempat yang berkecenderungan untuk nyamuk membiak. Lazimnya, penyemburan asap atau fogging dijalankan bagi membasmi pembiakan nyamuk aedes dalam usaha membanteras wabak denggi di seluruh negara. Contoh berikut menunjukkan penggunaan kata fogging dalam bahasa Melayu:

Contoh 23 Semburan asap (fogging) yang dijalankan oleh pihak kesihatan merupakan langkah untuk mengurangkan kehadiran nyamuk atau jentik-jentik di kawasan sasaran seperti longkang, takungan air dan sebagainya.

Ayat yang ditunjukkan dalam contoh 23 menunjukkan peranan leksikal fogging sebagai kata kerja dalam binaan ayat tersebut. Perkataan fogging itu sendiri dipinjam daripada bahasa Inggeris dalam konstituen ayat-ayat dalam berita atas talian tersebut. Penggunaan perkataan fogging dalam berita tersebut bersesuaian dengan laras-laras bahasa dalam berita agar lebih mudah dan difahami untuk menyampaikan makna maklumat tersebut. Dari sudut slanga remaja Iban Sebuyau pula, Informan 6 menyatakan bahawa perkataan fogging digunakan untuk merujuk perbuatan merokok. Pemilihan perkataan fogging untuk merujuk perbuatan merokok disebabkan ciri-ciri fogging sendiri yang menggunakan bentuk mesin yang mempunyai batang untuk mengeluarkan asap. Makna asal fogging yang diterbitkan daripada perkataan fog yang bermaksud kabus dikira berkait rapat dengan penciptaan slanga remaja Iban Sebuyau. Berikut merupakan contoh kata slanga fogging dalam slanga remaja Iban Sebuyau:

Jadual 8 Penggunaan kata fogging dalam SRIS

\begin{tabular}{|l|l|l|}
\hline Data & SRIS & Terjemahan Dalam BMS \\
\hline Contoh 24 & John, aram tua fogging sebedau nganjung padi. & John, mari kita merokok dulu sebelum menghantar padi. \\
\hline Contoh 25 & Anang ka fogging ba mua nembiak. & Jangan merokok di hadapan budak-budak. \\
\hline
\end{tabular}

Melihat kepada contoh-contoh dalam Jadual 8, penciptaan kata slanga fogging tersebut oleh remaja Iban di Sebuyau mungkin berdasarkan sifat-sifat fogging machine yang mengeluarkan asap sebagaimana yang diaplikasikan untuk menunjukkan sifat asap rokok yang dihembuskan. Sehubungan dengan itu, pemikiran remaja Iban Sebuyau diilhamkan daripada penyembur asap tersebut. Kreativiti mereka cenderung untuk mencipta slanga tersebut melalui peristiwa yang dilihat dan ciri-ciri yang ada pada mesin penyembur itu. Situasi semasa menggunakan leksikal slanga ini ketika kelompok remaja dalam perbualan seharian mereka. Pola peluasan makna oleh Kerangka Kategori Jaringan Radial dapat diperhatikan seperti berikut: 


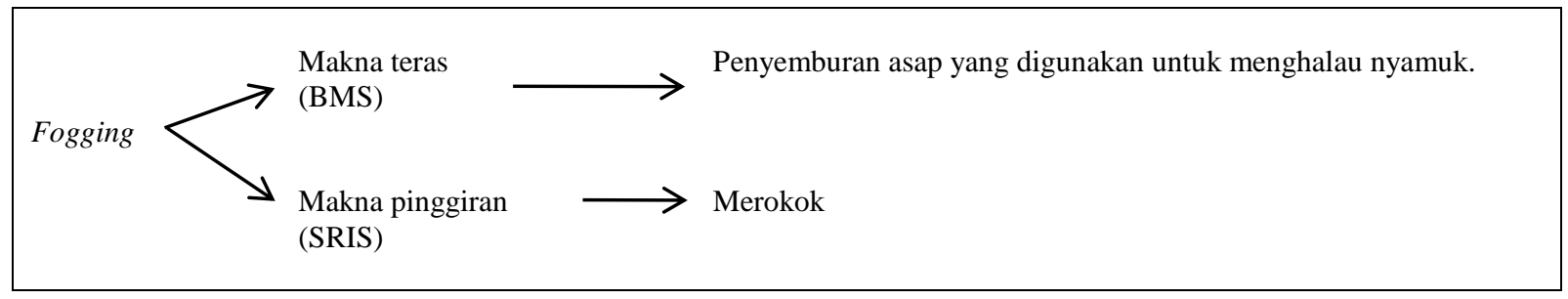

Rajah 10 Peluasan makna fogging dalam SRIS

Peluasan makna berdasarkan Kerangka Kategori Jaringan Radial dalam Rajah 10 pula memaparkan sifat yang ditunjukkan oleh fogging machine tersebut menunjukkan keadaannya yang mengeluarkan asap atau kabus. Sehubungan itu, fungsi fogging machine yang mengeluarkan asap atau kabus tersebut mewujudkan kreativiti remaja Iban Sebuyau untuk mencipta kata slanga fogging itu. Makna itu diperluaskan unjuran daripada pengalaman dan persekitaran yang mereka lihat. Skema imej tersebut memberi gambaran bahawa asap rokok itu umpama asap atau kabus daripada fogging machine tersebut. Jadi, pendekatan Kerangka Kategori Jaringan Radial dalam penulisan ini berhasil untuk merungkai peluasan makna leksikal slanga yang dicipta dalam kalangan remaja Iban Sebuyau.

\subsection{KESIMPULAN}

Kesimpulannya, kajian yang melibatkan slanga remaja Iban Sebuyau ini menampilkan kelainan dalam fenomena berbahasa berbanding dengan penggunaan bahasa yang standard. Hal ini dapat dilihat melalui pemerian makna sesuatu kata slanga tersebut. Makna konotatif sesuatu perkataan slanga remaja Iban Sebuyau memperlihatkan penghuraian oleh pendekatan Kerangka Kategori Jaringan Radial yang disarankan Lakoff (1987) ini berhasil untuk menganalisis kosa kata bahasa slanga kategori kata kerja ini dalam kalangan remaja Iban Sebuyau. Penciptaan kosa kata slanga ini diambil berdasarkan pengalaman dan persekitaran mereka yang terbentuk dalam kognitif remaja. Golongan remaja sangat mudah untuk mencerapi makna sekaligus memberi ilham kepada mereka untuk mewujudkan leksikal slanga itu. Terdapat beberapa faktor penggunaan slanga dalam kalangan remaja Iban Sebuyau, Sarawak. Antaranya ialah mereka menuturkannya ekoran kata-kata yang dilihat sangat mudah untuk disebut seperti merueh, ngaga' peta, ngangat nyawa, belagu, nunjuk langit, melabur, dan fogging. Penggunaan leksikal bahasa slanga dalam kalangan remaja Iban Sebuyau juga didorong oleh faktor-faktor bergurau sesama rakan dan menyembunyikan makna sebenar misalnya, slanga kencing digunakan untuk merujuk perbuatan menipu padahal perkataan itu sebenarnya bermaksud membuang air kecil (Sulaiman et al., 2012). Selain itu, penggunaan slanga ini juga lazimnya digunakan untuk memaparkan identiti kelompok sosial tertentu. Pengaruh rakan sebaya juga memainkan peranan dan impak yang besar dalam penggunaan slanga (Sulaiman et al., 2012). Dalam pada itu, Kerangka Kategori Jaringan Radial oleh Lakoff (1987) ini telah merungkai makna pinggiran bahasa slanga sebagai kefahaman khususnya kepada pembaca dan pengkaji-pengkaji bahasa yang akan datang. Akhir sekali, penyelidikan sebegini dapat memperlihatkan fenomena penggunaan bahasa golongan remaja masyarakat Iban di kawasan Sebuyau, Sarawak. Kajian-kajian ini diharapkan dapat memberikan sumbangan yang bermakna kepada pengkaji bahasa yang lain untuk memperkayakan lagi kajian-kajian dalam bidang linguistik.

\section{Rujukan}

Ayub A, K, M. (2016). "Rosak Lagu Kerana Bahasa.": Pelita Bahasa. Kuala Lumpur. Dewan Bahasa dan Pustaka.

Baba, H., H. (2002). Peluasan Makna Kata Sifat Tabii Dan Kata Sifat Indera Sentuh: Analisis Semantik Kognitif. Bangi: Fakulti Sains Kemanusiaan Dan Kemasyarakatan, Universiti Kebangsaan Malaysia.

Baharuddin, S., A. (2012). Modul Hubungan Etnik Edisi Kedua.. Bangi: Universiti Kebangsaan Malaysia.

Bloch, B., \& Trager, G. L. (1942). Outline of Linguistic Analysis. Baltimore: Linguistic Society of America/Waverly Press.

Bup Sereba Reti Jaku Iban. (2011). Kuching: The Tun Jugah Foundation.

Chaedar, A. A. (1993). Pengantar Sosiologi Bahasa. Bandung: Penerbit Angkasa.

Eble C.C. (1996). Slang \& Socialbility. The University of North Carolina Press Chapell Hill and London.

Hashim, N., Mahmoor, N. A., Ahmad, A. A., \& Yahya, M. A. (2016). Bahasa Slanga Dalam Komik Kanak-Kanak. 2nd International Convention on Islam, Science \& Education. ISBN:978-967-5852-35-0

Izmaylova, G., A., Zamaletdinova, G., R., \& Zholshayeva, M., S. (2017). Linguistic and Social Features of Slang. International Journal of Scientific Study. September 2017, 5(6), 75-77

Kamus Dewan Edisi Keempat. (2015). Kuala Lumpur: Dewan Bahasa dan Pustaka.

Kamus Dwibahasa Oxford Fajar Edisi Keempat. (2008). Selangor Darul Ehsan: Oxford Fajar Sdn. Bhd.

Lakoff, G. (1987). Women Fire and Dangerous Things: What Categories Reveal About The Mind. Chicago: Chicago University Press.

Majalah Pegari.(2013). Bintulu, Sarawak: Pegari Iban Production.

Mohd. Ali, H., \& Abd. Rahim, N. (2011). Perlambangan Kata Kerja Dalam Lirik Lagu "Bebaskan" Berdasarkan Teori Relevans. Journal of Business and Social Development, 5(1), 102-111

Mutonya, M. (2007). Redefining Nairobi's Streets: A Study of Slang, Marginalization, and Identity. Journal of Global Initiatives 2(2), 169-185

Nguemo, M. (2016). Slang as Mean of Exclusion From In-Group Communication of Selected Undergraduates of the Ahmadu Bello University, Zaria. Nile Journal of English Studies.Terna-Abah, M, N./NileJES; April 2016.

Omar, A. H. (2015). Kaedah Penyelidikan Bahasa Di Lapangan (2nd ed.). Kuala Lumpur: Dewan Bahasa dan Pustaka.

Omar, A. H. (2015). Nahu Melayu Mutakhir (5th ed.). Kuala Lumpur: Dewan Bahasa dan Pustaka.

Pradianti, W. (2013). The Use of Slang Words Among Junior High School Students in Everyday Conversation. Passage Journal, 1(1), 87-98.

Samarin, W. J. (1967). Field Linguistics, A Guide to Linguistic Field Work. New York. Fifth Avenue.

Sariyan, A. (2007). Perkembangan Falsafah Bahasa dan Pemikiran Dalam Linguistik. Petaling Jaya: SASBADI

Sarudin, A., \& Jalaluddin, N. H. (2017). Analisis Semantik Kognitif: Kata Serapan Arab-Melayu. Kuala Lumpur: Dewan Bahasa dan Pustaka. 
Sintian, M. (2015). Penggunaan Slanga Dalam Kalangan Pelajar Kadazan Dusun. Conference Paper November 2015 . Universiti Pendidikan Sultan Idris.

Subet, M. F., \& Daud, M. Z. (2017, August). Semantik dan Makna Konotasi dalam Slanga Pelacur. Paper presented at The International Conference on Language Studies 2017, Kuching (Riverside Majestic Hotel). Retrieved from https://doi.org/10.17605/OSF.IO/6ZMR7 Access on 10 February 2019

Sulaiman, Z. M., Chien, G. K., Boon, E. S., \& Yusuf, A. H. S. M. (2012). Slanga Remaja Melayu dan Cina: Analisis Awal Berdasarkan Teori Relevan. Paper presented at 2nd International Conference on Arts, Social Sciences \& Technology, Penang, Malaysia.

Teo, K., S. (1996). Slanga: Satu fesyen Pertuturan. Pelita Bahasa. April 1996. Jilid 8 Bilangan 4. Kuala Lumpur: Dewan Bahasa dan Pustaka.

The Borneo Post Online. (2019). Sarawak Government, State Govt will continued to prioritise developing rural, coastal areas. Dimuat turun melalui https://www.sarawak.gov.my/web/home/article_view/229/188/ . (Access on 03 November 2019)

UNICEF. (2011). Adolescence An Age of Opportunity. USA. United Nations Plaza, New York, NY 10017.

Yusob, K., F. \& Zakaria, M., Z. (2016). Penggunaan Bahasa Slanga dalam Filem Tempatan: Satu Kajian Terhadap Filem Cereka Aksi. KONAKA 2016

Zhou, Y., \& Fan, Y. (2013). A Sociolinguistic Study of American Slang. Theory and Practice in Language Studies, 12(3), $2209-2213$. 